


\section{The Journal of the East Africa and Uganda NATURAL HISTORY SOCIETY}

April, 1924.

Special Supplement No. 2.

PATRONS.

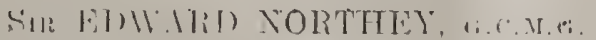

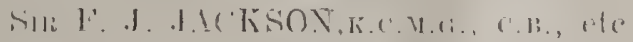

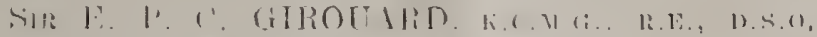

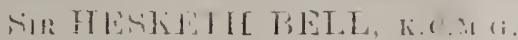

PRESIDENT.

HIS EYCELLENCT, SIR ROBERT CORYNDON, K.C.M.

\section{VICE-PRESILENTS.}

Hox. E. B. DENHAM, C.M.G., B.A. OXON.

A. B. PERCTYAL, EsQ, F.Z.S., I. ..o.t.

EX. COMMIYTEE.

F. BATTISCOMBE, EsQ., F.I..S, ASEOC ARBOR, SOC.

REY CANON ST, A. ROGERS. M.. nXOX.. F.E.

CAPT. K. F. 'i'. CALDIVELL, 1.1. CMI, F.Z.S., F.R.G.S.

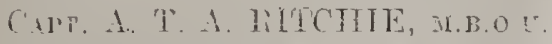

('. J. WHLON, M.A., M.г, в (H., M.R.C.S., L.R.C.P., M.

1?. F. MAYTR, TSQ., С.C.I., I.I. .

A. J. JEX-BIAKI. M.D., F.R.C.J.LD,

C. J. J. T. BARTOX, M.A., CAM., F.R.A.

HON. TREASURER.

KFY, J. IVESLEI HUNT, F.E.S.

HON. SECRETARY.

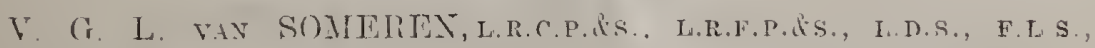

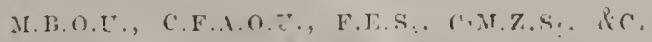

HON. EDITOR OF JOURNAL.

Dr. Y. G. L. VAS SOUERTI. 



\section{EDI'ORIAL.}

The object of this special supplenent is to enlist your interest in the Musem and the activities of the East Africa and Uganda Natural History Society.

It is felt that the time has now arrived for the sociely to appeal to the many in this Colony and Uganda who, by willing co-operation, can help in the work which the Society has undertaken.

The main objects are the establishing of a permanent Economic Muscum, in which will be exhibited examples of the actual and potential natural wealth of this country, its Fauna, Flora, Geology, etc., etc., and the publication of a Journal for the dissemination of knowledge on the above subjects and the recording of original research.

There is no doubt that such collections will prove of the greatest interest to residents in and visitors to this country, and of the greatest scientific value to other countrics.

This country is developing rapidly, and the work of getting together materials for these collections cannot begin too soon.

Many peopie are unaware of the existence of this Society and are ignorant to the fact that a Museum is already established; a brief outline of the history of the Society is therefore appended in the hope that those interested will endeavour to support the Society by becoming members, and contributing to the collections.

'The Society includes in its membership, not only those who are trained naturalists, but also the potential naturalist, the lovers of Nature who reside on farms and in outlying stations, who, if their observations can be directed into proper channels, may obtain materials and make observations of the highest importance. We are nearly all amateurs, and our only claiml for union must be our common love of Nature in one or more of its phases, and the intercourse of such a Society as ours cannot fail to stimulate enthusiasm in this most wonderful country.

There is no country in the world so rich in fauna and flora of an attractive and interesting character, or one where the opportunities for research and original observations are so easily available, and the results of obserrations when published in the Journal must prove of great scientific interest and form a record unique in character.

\section{BRILE' HISTORL' OF' 'THE SOCLE'TY.}

There had long been a desire on the part of many interested in Natural History in this comntry that a society should be formed to bring togrether for mutual benefit all lovers of Nature throughous Uginda and Last Africi. To this end, a Socioty was founderl in the early part of 1909 , by a band of enthusiasts, under the presidency of Sir Frederick Jackson.

'The Public were informed and individuals eircularised. 
The response wain gratify ing and by the end of lolo the Suciety Was dinnly established. Interest was mantaned and tumb ace monlated, resulting in the rociedy deciding to extend its activities hy publinhing a Journal and costablishing as small Museum. Journel No. 1 appeered in 1910. (No. 19 is mow reaty for the Press).

A small building wals erected by $\mathrm{M}_{1}$. Jeevanjee and rented hy the society at a nominal figure. This was the beginning of the Museum. In the carly stages of growth the socicty derired great financial help from Sir Sortirup MeMillan and sir Henry Belfield, the former giving an anmual grant (discontinned in 1918), the ladter inaugurating a Building Fund, which in 1915 rearled the sum of $£ 400$.

The collections in the Mrseum increased so rapidly that the Hon. ('urators were mable to cope with the material which Howed in. A. full-line, trained Curator Wa- engaged fron Home in 1914

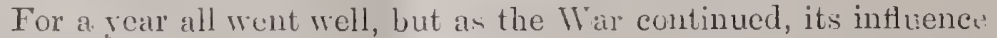
became felt, the membership deched, and the Curator was called up for Military duty: the activities of the sinciety were thus curtailed. Towards the end of the $11 \mathrm{ar}$ interest was re-established, and the suricty wcut ahead with renewed rigor, the membershup increasing frcin just over 100 to about 350 .

At this juncture the Socicty wis faced with the problem of finding increased accommorlation for its growing collections. This difficulty was solved by the Committee deciding to utilise all available funds for the rection of a large permanent Museum on the plot of land between Fink licad and sixth Arenue, reserved for the purpose by Goremment. By November, 1922, this building was completed, but to meet the cost the society had to rom into debt.

From time to time the Society has approached Government with at view to obtaining a grant in aici, but so far unsuccessfully.

By careful husbanding of funds the rlebt has been reduced to a small stum, riz., $t 200$, but other expenditure such as that on the Journal hat harl to be curtailed. The recent general depression has been reflected in the finance of the suciety, several members failing to renew their annual subscriptions. Efforts howerer have recently bcen made to recoror lost ground and so far an increase in the collection goes, prospects are decidedly brighter, in fact the Societr is again faced with the urgent nced of securing a eompetent Curator to look after the exhibits on show and in store in order to prerent their certain and rapid deterioration.

It is hoped that Gorernment will ralise its responsibility and sillyort the sociely.

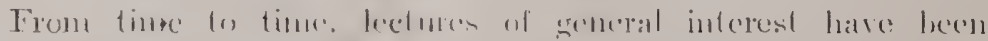

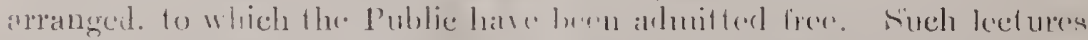

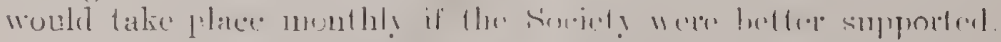

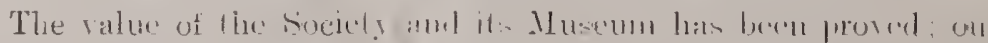
frequent occasions valuable soree has leen rembered fo fioremment

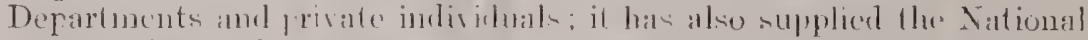

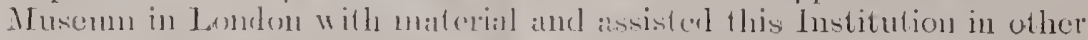
Ways. The Muscum has come to stay; it is the only public institution in this country for the advancenent of linowledge, its seope is extremely wide and its adrantages are great. 
Lhe society and the Museum are in no way eomected with Gofermment, nor alle its member's all oflicials; anjone is weleome to join, ladios equally with men.

Ihuse member's of the Socicty who are experts in one or more

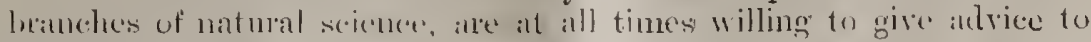
llose sereling it.

Elsewhure in this supplement will be found a notice, outlining the sulject matter to be dealt with in succeeding numbers of the Jomrmal. It will be noted that there articles when completed will become standirl ?ext-books on the respectire subjects dealt with.

At the end of this publication will be found application for Menulership, Forms, Bankers Order, and Forms for Jonations to ripecial Funds.

The commitfee hopes that this cncleavour to loring the Society and its activities before the Public will meet with a genemon response and that thereby the society maty be cnabled to carry on its laudable endlaroms with renewed cnergy.

This Society should be in a position to cilry out proper zoological or biological surveys of various districts and to command financial aid from Govermment, both local and Home, and from Scientific Borlies abroad.

A glance at the literature of scientific institutions will reveal the limentable fact that those who have contributed most to our knowledge of the country we live in are not local residents but visitors from America, Gemany, Sweden and cren Switzerland; and a mere handful of Britichers from Home, while we on the spot have done practically nothing. What do we know of the biology of that huge inland Sea, Victoria Nyanza; what of the coast waters, of the towering snow-clat mountains, of the raterless tracts of desert country; of the huge bow-lying swamp areas across Lake Kioga?

A yall or two ago fovermment granted permission to a Swedish Fixpelition to reset and establish a Biological Research Station on Mit. Flgon, smilar to that of the American Institute in Brmsin Guiana. Now why should strangers be allowed and cncouraged to cxplcit the vast ficld f for research of Britsu territories?

IIill the people of Kenya not help to eradicate this blot which looms larese on the fair countenance of the country we love?

- The Committec earnestly solicits your help to push forward the wots of an institutinn which is conducted for Fiducation, for Science, for the T'eople. 
GAME PRESERVATION, ITS AIMS AND OBJECTS.

[By CAPT. CatdWELLi, F.z.S.]

Lecture delivered before the Kenyu and Uganda Natural History Socicty on March 14th, 1924.

Jolr Excelifincy, Ladies and Gextlemex,-

I will, if I may, take as my text the words of Dr. II. T. ITnmaday, Tresident of the New York Zoological Park.

"Ihe wild life of to-day is not wholly ours to dispose of as we pleasc. It has been given us in 'TR'st. Wr must account for it to those who come after us and audit our records."

The aim of the Game Department is to preserve Game; and the object is to preserve it in such a way that it does not in any way retard or interfere with the economic development of the country, or place any difficulties in the way of stockbreeding or crop growing.

Most people have a very wrong idea of Game. Ninety-nine per cent. of the people imagine that the Game of the country belongs to the Game Department. That is not the case. The Game does not belong to the Game Department, but to the people of the country; and anyone doing an injury to the Game, is doing so to the people of the country, far morc than to the Game Department. If the people of the country would-get into their minds the idea and conviction that the Game was their possession, and not the Game of the Game Department, we should get a better public spirit in regard to Game than we have to-day.

The whole of public opinion in this enuntry badly requires instruction. The question is sometimes asked, why do we need a fame Department? Why cannot other Departments do the work? That is everybody's business is nobody's business and in a country like this, a Game Department has a special sphere of its own-one that other Departments cannot fill. To start with, the work of the Game Department (unlike other Departments) lies in the uninhabiter parts of the country where there is nobody to help. Where there are no natives and no white men is where you find most game. One unhappy suggestion was made that the Agricultural Department should undertake the Game Department's work-another idea was made that the Forest Department might do it, since it carries out this work in India. In India most of the Game is in the Forestsin Kenya it is not.

The Game Department pays. The total cost of the Department last year was $£ 4,000$. In licences alone there was taken $£ 8,000$, and the profit on ivory amounted to $\$ 16,000$. I want to draw attention here to an extraordinary belief current in many 
parts of the this country, (I even found a Legislative Councillor who suffered from it) and that is, that the Game Department get the moncy that results from fines and money from confiscated ivory. They don't-I only wish they did. It all goes straight to the Treasury. If the Department-scnds out a special safari, and gets a thousand pounds' worth of illicit ivory, even the cost of that safari may not be charged against the ivory.

As I have said, there is a large amount of money made by the Game Department and, so long as you have the game, you will go on getting that revenue. Once you let your game go, you will lose the money. For an investinent of $\downarrow \pm, 000$ a year you get $£ 23,000$, of which $£ 19,000$ is profit: but unless you preserve the game you are not going to keep on getting that money. Countries in which game abound are not very plentiful, and if you once let your own game go, you will find that it is difficult to get it black again. You cannot rear it like pheasants in England; and we cannot get it from our neighbours, so if you let it go, it will go for ever: that is the end of it.

South Africa has found this out. They did not keep their game in trust, and, as a result, they in South Africa have very, very little game-practically none-whereas in the old days they had almost as wonderful a collection as we have in Kenya. In their endeavour to keep what is left, they employ eight Europeans and 100 native police patrolling a game reserve the size of our southern reserve, where we have four scouts. Imagine the cost, and remember that they get no revenue to counterbalance it.

The amount spent in Anerica on game preservation is greater than the total budget of this Colony. If the Americans had looked after the game at the right time, they would not now be called upon to spend one per cent. of what they do expend.

There is a popular idea that the one object of the Game Department is to pounce upon game law offenders, and get very large penalties imposed. The Game Department is, first and foremost, technical advisor to the Government on all points connected with the game. It is responsible for recommending alterations in schechules indicating greater liberty or further restriction in the shooting of certain species. The Department has also to watch the contact of game with agriculture and the economic development of the country. Lastly it has to watch the balance of nature and act as and when possible.

During the great outbreak of rinderpest in the southern game reserve some years ago, and in the great plague of pleuro pneumonia, cattle died in thousands. The liyenas had a splendid time, and they increased so rapidly that when crattle stopped dying, they had, in order to survive, to give up their habits as seavengers, and become liunters and liller's of game. The serious decrease in the game in the southern reserve is due, more I think to hyenas, than to anything else at the present time. I have even seen a lioness bayed up at the foot of a tree by a dozen hyenas in broad daylight. It is easy to realise how tcrribly destructive a pack like this is to a newly born and young buck. An intensive poisoning campaign is necessary to reduce the numbers of hyenas and restore the balance. 
The kejnote of all game priservation is PILEVENTION of IiLLiNG lor Profit. 'There must be no general system of making money out of the destruction of game.

An exception is made in the case of ivory. The Government says that if you like to take out a $\$ 10$ Resident's Licence, and a $£ 15$ Elephant Licence, you may get an animal with trophies worth $\$ 75$. On the other hand, you may not. We bet you three to one against, and you talie rour choice. I am often asked, why not allow people to shoot the elephant first and take out the licence afterwards? That is to say, let the hunter get his £os animal, and then pay his $£ 25$. But that would be allowing killing for profit; and killing for profit, as I have said, is the end of game preservation. Killing for profit was the cause of the great externination of game in South Africa, and wiped out the bison in North America: the door to it must be banged, bolted and barred. On the face of it, it seems unjust, that a farmer who wishes to kill off game on his land, should not be allowed to export the hides for sale, when he has done so. To pernit this would allow a loop hole which it would be impossible to close, and which would cause an cnommous slaughter of game on Crown Land.

Until three rears ago, rhino were included on the ordinary lieence. One could be shot on Crown land, and as many as you liked on private land; but the slaughter became so great, that to keep a check on rhino killing, these animals were put on a special licence which cost $f 5$-about the value of the homs. The supply of rhino horns did not diminish; and when they were produced, they were always supposed to have been killed on Private Land previous to 1921. A notice was then inserted in the Offcial Gazette, and in the Press, stating that all Rhino horns in the possession of private individuals had to be registered; and that, failing production of the registration certificate, or the special licence under which the animal was shot, such horns were liable to confiscation.

The result has been to help to shut down the rhino horn trade, and to sare the lives of a number of animals which were being killed for profit.

Take another instance of profit killing. Colobus and Blue monkey-since their skins have a market value, they were put on the list of scheduled game animals (i.e., animals that may only be ohtained on a licence); but a big trade in them is still going on. The native finds that he can get a price for them from the whitcman, and accordingly lills to sell the skins. Tn spite of the confiscations and prosecutions that have taken place, the Department finds it very hard to make the reneral public realize that it is an offence to purchase these slins from natires.

There must be some definite relationship, between the value of the trophies you can obtain, and the cost of the licence. If you make the licence fee too low, vou get a certain class of people-and this country is not free fron them-who will take out a licence, not for the salse of sport, but with the idea of making money out of it. And the making of money out of the game is the danger which must be watched rery closely. 
People often say, " Why do you use native scouts to wateh and catch white men?" At the prosent monent, wo have llureo Europcans in the Department. During most of 19:23 1 was single handed. How are you soing to catch malefactors in a country such as Kienya with the present staff:? Nobody regzets the necessity to use native scouts more than I do. 'They harc no itca of chronclonical sequence; and in consequence, frequently contradict each other in natter's of detail. 'They toll their stories in court in a manncr which suggests a " frane u]," but the essence of the stor" is usually true. If we had an adeyuate stalfi", we could hale at whiteman near the spot, and he eould investigate the cise then and thore-obtain proper evidence, and take what action was necessary. As it is, we are working under great difficulties. I would like to talie this oprortunity to point out that native scouts are not used on Private lambl-they are employed, like all the slender resources of this Department, in protecting the Crown Land Game.

Native Scouts hare their ures all the same. A few days ago, two of then, working in the Masongaleni Distriet, got into tonch with Iwo rery bic tuslis from an elephant that had been killed by II akambil. On their attempting to take possession, they were driven off by poisoned arrows. In the end, thanlis to the co-operation of the police, to whom I tender hearty thanks, the party were arrested, and the tusks, weighing 158 and $149 \mathrm{lbs}$. respectively, recovered. 'Tlongh not the biggest linown, there is only one longer pair on record; whilo for weight, they rank fifth or sixth biggest, according to Rowland II ard's book.

One of the difficulties which the Game Department has to face in its work, is the "flabby" state of public opinion. Hitherto public opinion has been extremely " flabby." Curiously enough, it is not "Habby " where giraffe is concemed. The general public like to see their giraffe; and anybody who kills giraffe, unless he does so very quietly, will be reported straight away. That is why you can find many giraffe in the settled areas.

On the other hand, anyone who kills rhino-which is quite a rimple thing to do-is thought to be rather a hero. Why this is so, I have never been able to discover. Impalla are also very popular, and anyone who kills them is likely to suffer from public opinion. I want to see public opinion improve until it embraces the whole of the very large number of animals we have. There is an improvement, but there is istill a long way to go. If the country mould realise that the game butcher is a very undesirable citizen, incl treat him as such, we would be able to do much better.

Honorary Game Wilrdens hare proved to be a tremendous sucess. Their appointment was an experinent, but it has fully

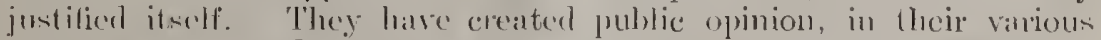
districts, and mate prople see things in a new lighls. Many of those with whom they have come into contact have come round enormously, and are prepared to do a great deal to help the Department, and the IIonorary Game Wardens.

One subject in regard to which propaganda is required, is the habit of feeding safari porters on ineat. It is often, not so much to get food for the porters, as an exeuse for the shooters to loose off 
their rifles. I do not mean that it is never neeessary to give porters meat; but valuable game is teing killed in a very wholesale way. A great deal of this killing is totally unnecessary:

The real root of the depletion of the bigger game to-dayelephant, and rhino- is the native humter. You do not see the native hunters near Nairobi, or in the settled areas; but further away, lemote from the administration, you come on their tracks. In the old days they lived on the game for meat, and the game and they got on very well together. When you have the money-making and profit element introdueed, you get a totally different state of affairs. North West 'Tanaland and Jubaland were, at one time, the homes of rast herds of elephant. The Masai were not hunters; the other tribes merely killed for meat and the elephant and rhmo inereased and multiplied in enormous numbers. Then came the Somalis from the North. By reason of his extraction and nature, the Somali lives on the country he comes to; he saw at onee that the easiest things to be taken out of the country were ivory and rhino horm. He used the tribes as hunters and exported ivory-our ivory-and rhino horin. The great obstacle to putting down this trade is the existence of a "fence" or reeeiver, to wit Italian Somaliland. Imagine the position of a poliee foree if, on the outskirts of a large eity, there was one shop, which was above the law, and whieh eould openly deal' in stolen goods.

Barawa and Mogadiscio are entirely free ports for ivory. They will accept ivory, no matter where it eomes from, so long as they make something out of it. And so long as you have a free port, it is impossible to put this smuggling down. The trade is estimated at from $£ 30,000$ to $£ 60,000$ or $£ 80,000$ a year. Barawa practically lives on our ivory. The only real cure is to get Italy to co-operate, and to conform to the Ivory Convention to which she was a signatory. so long as you have "Free Ports " in Italian Somaliland, you have a receiver, above the law, ready to take everything. People sometimes say, "Why ean't you catch these smuggler's?" "What are the King's African Rifles doing?" Well-they are doing all they possibly can; but Tanaland and Jubaland are huge, waterless countries, densely bushed, great tracts of which have never been erossed by a white man. The Somalis usually move at night, and if they think they are in any danger of observation, bury their tusks by day in the sand. They then sit down, and you ean watch them for a week without finding anything out. If they are really frightened, they can leave the ivory altogether, and come baek in six months, or a year, and be sure of finding it. Another of their methods is to break the ivory up into pieces, and use it to stuff the " herios " or camel mats. In a district where camels are moving in thousands, the examinlation of every camel mat is an impossibility. This smugrgling is roing on all the tine in cvery dircetion. One safuri recently caumht by the King's Africin Rifles with $\& 1,200$ wortl of tusks, is now believed to be the thirteenth that laad recently passed; and only half the thirteenth at that!

As a temporary way to eheck the trade, we are now trying a system of rewards. Somalis will do most things for money; and onee they realize that they will be rery handsomely rewarded, and that their names will be kept dark, they will, I think, be ready to 
give information. At present, they we rather afraid there is some catch in the scheme, but information is beginning to come in. Any method of this sort can only be pallictive: I am sure you wrill agrec with me, that the only final and sitisfactory sqlution is Italian Co-operation.

As is well known, Goremment pay a reward of up to shis. 4/.; per lb. for irory brouglit in under the fiction that it is " found ivory," i.e., oli irory from elephants that have died in the bush. I say " fiction," because, although the bringers' hands are supposed to be clean of the killing, it is impossible for the receiving officer to tell how old the tuskis are, and how they were acquired. The usual game is to bury the tusks in cow dung, fill up the hole, and light a small fire on the top. After a few weeks of this treatment, the ivory looks as though it belonged to the linst century.

'Jhe bringer of the irory, usually an unsophisticater native, does not profit by his grins, for he is hardly clear of the District Commissioner's Oftice, when le is surromded by smart routhe who take them off him by the "three card trick" and similar deviecs.

But unless we give the reward-sometimes Shs. 300/- instead of Shs. $40 /$ - or Shs. 50/-, which should be sufticient-the ivory will go up to Italian Somaliland, where the buyers are always ready to pay big prices.

Rhino horn, much in demand in China, is another attraction to the smuggling fraternity. Considerable quantities get out concealed in libuyus. It is so easy. All that has to be done is to cut the bottom of the kibuyu, put in the Rhino Horn, stick the bottom on again, and fill the kibuyu. with ghee or any other commodity. Amongst the thousands of kibuyus passing through it is impossible, unless one has very good information, to know when this game is going on. A great deal of horn used to find its way to Zanzibar in trading dhows. I did not realise how much, until a few months ago, when I was in Zanzibar, and looked at the Customs Department's figures of import and export of Rhino horns. I then discorered that $\mathrm{R}$. 40,000 worth of horn was imported, and Tis. 100,000 worth was exportes, and eame to the conchusion that the Zanzibar Rhino must be in grave danger of extermination! I had an interview with the late Resident, Mr. Sinclair, and the Chief of Customs, (to both of whom our thanks are due) and it was decided that, in future, all Phino horn should only be allowed in on an import certificate-to obtain which, clearing papers must be produced-and no hom should be exported without import papers. This will stop the Zanzibar trade, but I fear that a good deal of it will only be diverted to Barawa and Mogadiscio. This is another reason for the absolute necessity for getting Italian Co-operation.

Another problem is the Dutchman. They are usually goor shots and expert hunters. When times are hard, they get what ther can with the rifle, and not infrequently live on the game. In their case it is a straight issu between the Game Department and the offender: I trust that, with increased staff, the difficulty will be overcome in a few vears. I hope that nothing I have said will be considererl a reflection on a law-abiding, God-fearing section of the population. It is only where game is concerned that they are other than an asset. 
A great deal has been sand and written about motor cars, and the influence they hare on game prescrvation. I an not seriously: concemed with tic clanger of netually shooting from a motor car, because the areas and opportunities to shoot from a car are limited. Where private land is concerned, and meat is wanted, it is fur better to go out in a car, lsill something, and hring it in, than lo send out n boy who will only wound half of what he sees. But the rit is at clanger, in that it enables people to get out to far parts of the country and back. Jou cannot keep track of their morements, or keep them under control. Then a foot safari eomes back, you can find out what has been done. If a ear alone has been used, this is not so. There are jeople in this comntry, who boast ears with special false bottoms and platees for the eoncealment of tuskis and rhino horns. Most of the best Game Districts are closed distriets under the 'Outlying Distriets Ordinanee.' I think the poliey should be, to get the administrative ofticers conecmed, to refuse permits to persons, exeepting those of linown interrity, whose safari consists of a car and mothing clse. I submit that this is neecsary for the sake of the game, and the preservation of the best shooting districts in the country.

Prosecution in all cascs of game offences is, I think, esinential: and it is the policy of the Department that every person, except those guilty of purely technical offences, will be dealt with. If you always run anyone contravening the Game laws, you can never be accused of maling distinctions! It is always difficult to prove game offences, and to obtain evidence; and the lawbreaker will take the risk if the penalty is small. Therefore, the only real deterrent to breaches of the Game laws, is the knowlerlge that conviction will carry a heary fine.

1 reform I would like to see made, is the registration of white hunters. At the present moment, when a white hunter talies out a safari, he may find that his employer is a curious sort of fellow who says: "Never mind the Gane Laws. Why should I not shoot? Who is going to know?" "It is often impossible for the white lumter to object; he is in an unfortunate and unfair position. All over Imerica the taking out of uhite hunter's is encouraged: in many linces it is compulsory. All white hunters are licenced and registered. The result is that the hunter is able to say to his employer: "It is all rery" well for you, but if anrthing happens. I may lose my livelihood." 'The hunter's certificate will restrain the employer, and take the responsilbility out of the white hunter's hands. By one move, the Department will gain control of all visiting safaris.

I do not believe very much in reduction of game schedules as a means of game preservation. It is rery difficult to enforce them with the present staff. Jou can run a man in, if you find him shooting on Crown Land without a licence; but if he holds a "Full" licence, and is frequently on safari, it is exceedingly difficult to prove a charge of overshooting. Toval Game we can deal with. but nnimals of which threc or four are allowed, get screrely overshot. the Coast.

One of our most raluable safeguards is the Customs search at 
P'eople who have trophies, that they want to get out of the

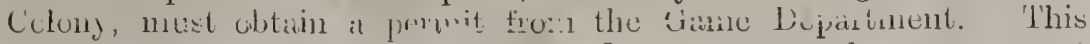
criables us, more or lesis, to keep a check, because the orner must moduce is liecrice to support his ommership of the trophies. If at Custons search only nueant the eonfiseation of illegally possersed rophics, people wouk not mind risking it; but as it probably entails lusing their boit, and forfeiting their passage noney, they think wiee-and generally decide the grime is not worth the eandle.

In eonelusion I want to refer shortly to the Grame Reserves. I trust they will be licpt in the future, as in the pinst, is crame " lieserves," not "Fresorves." I hare boen asked why we don't hure the lieences for millionaires to shoot there. This would be cntirely contrixy to the whole prineiple. A game Reserve is intended to be a place where the laws of nature liave full sway, and where animals cxist as they were before the introduction of fire arms. Once slooting is allowed in a Game Reserve, these eonditions disappear.

One rery desirable feature of a reserve is that it should have clearly marked boundaries; and we are lueky in having the railway line is the limit of the Southern Game Reserve. No one ean say, with any hope of being believed, that they did not see the boundary. Even the game itself very soon gets to know on which side of the line safety lies. Any substitution of the present line by an ill-determined rrbitrary demareation would be nothing short of disastrous. The suggestion has been made, that the Reserves should be broken up into a series of small reserves. The fallacy of such a policy is obvious. sinall reserves get burnt out. Game migrates and gets shot outside. Lastly, small areas suffer severely by poaching on their edges. With the experienee of the great rinderpest epidemic behind us, does anyone imagine that an outbreak of disease would be localized in a small reserve?

We are fortunate in having as our Governor a man with very: wide experienee of Afriean Game, and a deep knowledge of our difficulties and problems. The Colonial Seeretary has already taken "n grcat interest in the duek on Lake Naivasha, and will, I hope, take an equal interest in the rest of our game. Captain Ritehie, the new Game Warden, has wide technieal knowledge, and has studied game in other lands. We may rest assured he will do all in his power to ensure the preservation of the wild life of Kenya.

In reply to a question regarding Preservation of Game birds, Captitin Caldwell said :- -

'The problen of preservingr duck on Lake Naivasha is not diffieult. All that is necessary is for riparian owners to help to put dowm any trarke in wild ducks' eggs, and for Government to limit the whootiner season to the period when the mignatery duek ine on the l:1k:e.

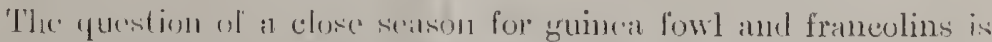
rery difficult indecel. 'That great naturaline sir Frederick Jackson "rote in mentiandum on the subject. and cane fo the conclusion that it. Wals inpracticalste. Leaving out the fact that the close season woukl hate fo vary for erery clistriet, how are you to prevent the native suaring birds either for his own consumption, or to sell to the Furopean? That is, I think, the crux of the matter. I do not mean that I ann against bird protection. Far from it; but I know of no sehene which would appear to promise suceess. 
The Journal is published as frequently as funds permit. T'he eontents are as varied as Nature herself, and include articles on Antliropology, Ethnology, Grnothology, Entomology, Herpetology, and the hundred and one other brauches of Scientific researeh.

'The Nlid'l' number of the Journal will contain the first instalnents of a series of Papers dealing with-

L'HE BJTRDS OF EAST AlRICA \& UGANDA. Illustruled. By Dr. Yal SOMLREN.

Commeneing with the Gane Birds; Francolin, Spurfowl, Guineafowl.

Quail, l'igeons, Ltc. This is of extreme interest to sportsmen.

TIIE BUTTERFLIES OF KENTA \& UGANDA. Illustrateü. By Rev. Canon Rogers \& Dr. van Someren.

PAPILIO DARDANUS. Brown:

A buttertly with a history, presenting many and raried eomplex problems. Illustrated.

By Professon Porton, Oxford.

These instahnents when eompleted will form complete I'extboolis on the subjeets dealt with.

\section{DO NOT FAIL TO SECURE 'THE COMPLETE SERIES.}

This can be assured by seeuring membership and signing the BANKER'S ORDER overleaf.

Other artieles will deal with Natural History subjects of general interest, ineluding a treatise on "The Birds of JubaLAND AND THE Northerx Frostier." This artiele is of particular interest as the ceding of Jubaland to the Italians will make colleeting in this region almost impossible.

\section{PRIVILEGES.}

A full nember is entitled to all publications of the Soeiety, issued during, and subsequent to the year of joining, provided the annual subseription is not in arrears more than ONE month.

M(mubcrs are armitted to the Museum. free on presentation of their Mombership ends, failure to do so renders them liable to the ordinary rharges. They may make use of the Library, and borrow books and periodieals under certain rules.

$\Lambda$ booklct of rules is enclosed. 


\section{LIS'T OF DESTRED ETHNOLOGICAL OBJECTS.}

1. Photographs, as linge as possible of

(1) Natives in native diess (man, women, children).

(2) Head alone, on larger scule, of man and women, front face and profile.

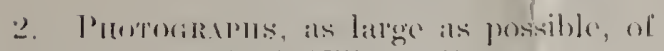
(1) "Villages."
(2) Individual Irul.
(i) Insirle of IInt.
(4) Thut in course uf comstruction.

$\therefore$ Spformens of the lineretere ow the Je'ts.
(1) Silreping mits.
(2) l'illuris.
(3) Stools, etc.

4. Spromejs of Maif: Ciothing and Ornaments. *
(1) Ordinary attire of man and youth.
(2) War-dress of Chief and ordinary tribesman

Spachens of ligmale ('lothing and Ornaments.*
(1) Girl
(2) Married wornan.

* Ornaments made of beards, tecth, shells, wood, thorns, spines, nuts, etc.

5. Specinexs of 1)omestic Appiances and Food.
(1) Baskets.
(2) Cooking pots.
(3) Combs.
(4) Needles.
(5) Thread.
(6) Sinuff-boxer.
(7) Ment-dishes.
(8) Slin scrapers for preparing skins.
(9) Cirain from which "beer" is made.
(10) Foods.

(6) Appinances for Agricultire.
(1) Hoes.
(2) Ploughs.

(7) WEAPONS.
(1) Battle axes.
(2) Bows and arrows.
(3) Assegais.
(4) Clubs.
(5) Shields.
(G) Traps and Snares for animals.
(7) Fish hooks.
(8) Rope. 


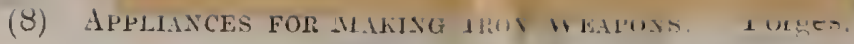

(9) ArTs.

(1) Carrings.

(2) Drawings.

(3) Etchings on bone, stone, ets.

(4) Musical instruments of all kinds, whistles, pianos, bows, drums.

(10) Mrincist:s, with their modr of applieation and the eomplants

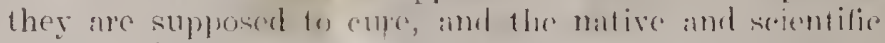
names of flants or animals fiom which they arm obtained.

(11) C'rtevs of all kinds and their smpposed vilturs.

(12) Inors and all objects of witeleraft. and worhipl.

It is, of course, rery nerescally that arery eperimen slonuld bes

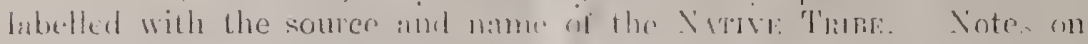
the Usis of THE OBJECrs and their native names would ard greatly to the ralue of the specimens. 
